\title{
Enhancing the Inheritance and Utilization of Regional Culture Resources in Art Design Teaching
}

\author{
Yu Fuyan \\ School of Art Design \\ Huanghe Science and Technology College \\ Zhengzhou, China \\ e-mail: daafu925@qq.com
}

\begin{abstract}
From the perspective of school teaching, under the guidance of the ideas and theories of modern design education, centering on the enhancement of regional culture research in art design teaching, this paper aims to carry out the study and practice of the regional culture in art design teaching in order to enrich the curriculum resources and develop diverse teaching modes. Combining the characteristics of art design disciplines with the target of talents cultivation by local colleges and universities, this paper tends to sum up the experience from the practical teaching and put forward a set of feasible modes and methods of enhancing the inheritance of regional culture resources in art design teaching through continuous exploration and practice.
\end{abstract}

Keywords-art design; regional culture; inheritance; utilization

In today's society, it has become an important trend to value national cultural inheritance in contemporary international education. In recent years, the relevant state departments have attached great importance to the protection and inheritance of regional culture, the works of which have been put on the agenda. Based on their own regional characteristics, the local colleges and Universities, taking the advantage of being in a favored geographical position, develop and utilize the regional culture as a kind of resource. It is not only conducive to open up the teaching characteristics of its own so as to gain the advantage of running the universities, but also plays a better role in talents cultivation, area construction and social services.

\section{PRINCIPLES USED FOR INHERITANCE}

\section{A. The principle of uniqueness}

The curriculum resources are of various types and due to geographical differences, some resources are of local characteristics. The development and utilization of regional culture resources should be in line with such local situations as economic conditions and current education situation etc. Teachers should bring regional superiority into full play, strengthen the school and local characteristics, embody the effective combination with art design education, play up strengths and avoid weaknesses and highlight personality.

\section{B. The principle of diversity}

When utilizing regional culture as a core resource in the art design teaching, we must take into account both the commonality and difference of students, which requires us to use diversity strategy. Diversity strategy refers to the concept that types and the presentation modes of regional cultural resources are diverse when regional culture resources are utilized. In the art design teaching, we can use the diversity of local culture resources, together with the discipline characteristics and the dominance of major subjects. We could utilize both on- and off-campus curriculum resources, material and conditional curriculum resources, pictures, texts, audio and video resources as well as material and activity resources etc. Diversification of types of art design curriculum resources and characteristics of the subjects determine the diversity of presentation modes.

\section{The principle of openness}

The principle of openness aims to change the traditional condition of regarding the teacher, classroom and teaching material as the center and achieve the realization of "studentcentered, activity-centered and life-centered" situation.

\section{1) The openness of teaching content}

All available resources in the local culture, in principle, can be used as new teaching content. The vast resources of art design courses determine the openness of the teaching content of art design. We can not only use the architectural and painting art, but also the sculpture and industrial arts etc.

\section{2) The openness of homework forms}

When we use the regional culture resources in art design teaching, we should get rid of the traditional forms of homework and eliminate the disadvantages of simple repetition. Instead of the traditional single form, teachers should turn to more popular forms of investigation, production, visiting, interviewing, paper-writing, small works making. Teachers should ask students to listen, communicate, think and explore thoroughly. Teachers should also integrate homework with the learning of art knowledge, development of art skills and the promotion of art accomplishment.

\section{The principle of situation}

Situational teaching refers to the teaching mode that teachers create a problem situation, organize the students to watch and review the simulation performance process which 
aims at resolving the problems so as to help students achieve a deeper understanding and the perfect mastery of course content. The principle of situation requires us not only to provide virtual but also the real teaching situation for students and it should provide the school context as well as the regional situation.

1) Using historical materials to construct the story situation

Every piece of art work contains rich humanistic connotations. The precious works of art with a long history, in particular, have profound cultural background and vivid anecdotes. In the theory teaching of such basic courses of art design as Chinese and foreign art history, teachers should make full use of historical facts to construct story situations, making the learning of art history course more interesting and vivid so as to strengthen students' understanding and absorption of knowledge.

2) Constructing activity situation with the use of regional resources

The local cultural resources include traditional buildings, parks and scenic spots, folk houses which can be used to serve the art design teaching. We can carry out research studies.

\section{THE TEACHING MODE OF UTILIZING REGIONAL CULTURAL RESOURCES IN ART DESIGN}

\section{A. The penetrating model based on classroom teaching}

Teachers should apply local knowledge, culture and experience directly or indirectly to the various major teaching of art design. By means of local resources, teachers should integrate the related ideas, beliefs, and knowledge in subject teaching and education activities. Resources utilization shows dependency and subordination. The utilization of regional cultural art knowledge into the design teaching could enable students to study the design theory and at the same time it could improve aspects of their traditional knowledge, expressive ability, creation attitude, emotion expression and expression way, etc.

The main form of art design teaching is based on classroom teaching and it should be the combination of art design curriculum and other resources. The integration of the regional cultural resources with art design teaching is based on the combination of general educational background and the whole subject. The regional cultural resources are allocated to each link of art design education in accordance with the characteristics and functions of their own, which embodies the relations between individual parts and the overall. The parts exist reasonably with life only in line with the overall.

\section{B. Seminar intervention model}

"Freshman Seminar" is in general the seminar course held in small classes by the famous university professors for freshmen. The main teaching mode is that the professor and the students in the group develop study modes on a subject together. Students conduct oral arguments and research training under the guidance of the professor. Freshman seminars aim to free the students from the passive receiver position, let students become discoverers and explorers of knowledge and enable students to make sure that the pursuit of knowledge, whether for their own sake or for the development of human civilization, is a valuable activity.

Compared with the "Freshman Seminar", "Senior Seminar" is held for juniors and seniors, which is the innovative and researching course with "research" and "discussion" as the main teaching methods. It helps encourage students to combine learning and thinking, develop cognitive interaction, and improve their ability to find, analyze and solve problems. It deepens the cognition of the course subject and knowledge system, enhances their creative spirit, practical ability and comprehensive quality, which helps achieve the innovative training mode of talents.

Seminar teaching mode makes the subject varied in form and rich in content, which further highlights the characteristics of subject, focus, system and target. Combined with the characteristics of various disciplines of art design, the seminar brings the profound resources of regional culture into art design teaching, enabling it to become a rich and colorful curriculum. On the one hand, teacher's guidance for students enables them to read and understand more of the local culture; on the other hand, it helps play the functional role of education, imparts knowledge and carries forward the local folk culture.

\section{Topic introduction model with project as the carrier}

The problem of how to link up local national folk culture with the modern art design courses is one teachers should pay more attention to; it is also a major issue in our local education reform. What needs to be emphasized is that valuing the local cultural tradition does not mean following the beaten track and excluding foreign culture, but to explore and search the combination of it with modern art design, making its features more obvious, so that it can gain a foothold in the world. Teachers could apply practical teaching methods as a means of responding to market demand. They could introduce the design task, transform knowledge elements of the curriculum principle, rules and methods for operational research, and integrate art design content into the local folk culture and the regional culture elements into the design of teaching so as to improve the teaching effect. In the project design, teachers should pay attention to the objectives, requirements, procedures, methods, style, skill and effect, while paying attention to practicality, operability, process, entertainment, demonstration and intersection.

\section{The comprehensive practical activity pattern}

Rich curriculum resources are not only the object and content of the research, but also the integrity of comprehensive practical activities. Under the guidance of teachers, students go to visit and investigate local natural landscape, cultural landscape, local craft workshops or art galleries, and museums for clear purposes, which helps improve their knowledge and skills and cultivates sentiments. Different local cultures create a large number of human landscape of different characteristics, for example, historic houses, the ancient stage, folk art, the local museum, and bridges, roads, walls, arches, and canals with a long history. These historical relics preserve rich cultural traditions and are closely related to the local folk customs. Moreover, they tend to be related to folk art by flesh and blood, or are representatives of folk art. Comprehensive practical activity requires students to study automatically, collect and sort native culture material, which can give full 
play to their initiative, cultivate their innovation spirit and practice ability and is conducive to broaden their knowledge and horizon to better develop their potential.

\section{THE SPECIFIC METHODS OF UTILIZING REGIONAL CULTURAL RESOURCES IN ART DESIGN TEACHING}

\section{A. Utilizing regional culture resources in art design course}

Due to its original ecology and dispersion, the regional culture resources determine that they cannot be directly used as a curriculum resources in art design teaching. The regional culture resources cannot be taken as the art and design curriculum resources directly, but there is a problem of transformation. The regional culture resources which are screened, refined and then applied in art teaching by teachers and students are the curriculum resources in real sense.

\section{B. Making full use of the natural resources and combining the basic teaching of art design and life closely together}

In the exploration of characterized art teaching, one objective is to actively guide students to observe the things around themselves, seek beauty in their familiar hometown, appreciate beauty in life and create beauty in painting. Such scenery is an excellent material resource for students painting. The fields, streams, trees and farmhouses are of respective characteristics. Teachers can lead the students to carry their portfolio, hold a brush and then draw a beautiful painting.

\section{Promoting traditional culture learning by appreciating architecture}

The regional architecture is extensive in meaning. Generally speaking, regional architecture is a way of expressing the different human cultural systems. For example, traditional East Asian Architecture in history was influenced by Han culture. It featured with wooden structures, while the European ancient architectural history is almost entirely stone, mainly with religious features.

The city gates, temples, towers, ancient ruins, ancient residential areas and landscape architecture are of strong nationality, age and educational meaning. They are the embodiment of architecture, sculpture, painting, crafts and decoration, which are of very high artistic value and the local cultural foundation. They could be flexibly applied into art teaching. In addition to letting students collect relevant data, teachers can also encourage students to view an architecture experience space in person, guide them to observe and perceive, let students understand the cultural connotation of arts in diversity, understand precious fine arts culture created by our ancestors, appreciate architectures of ethnic characteristics so as to create the works of art with the spirit of the times and ethnic customs.

\section{Exploring the essence of folk arts and crafts, providing folk arts teaching}

Because of the neglect of the inheritance of national folk art culture in our school education, the inheritance of folk art culture mainly relies on private families or social groups to perform and the activities are mainly carried out in rural and urban areas. In addition to spot-collections by teachers and students, university can also make use of local art and cultural resources, taking the approach of going out and bringing in, encouraging teachers and students to learn from society, conducting investigations, collections, collations and classifications of the local folk art material, making it available as teaching resources, or inviting local folk artists to deliver subject lectures, imparting knowledge of folk art to students and teachers. In this way, the combination of the subject events and discipline can make close combination of study and practice, the art teaching and folk heritage, so that students, teachers and folk artists could interact and it can make teachers and students have a better understanding of the local folk art and the real and objective perception and understanding of the functions, connotation, variety, style of folk art, enabling the local folk art culture to be collected, collated and effectively inherited by the social practice of teachers and students.

\section{CONCLUSION}

Following modern design trend, teachers should base art design teaching on local culture, view the traditional folk culture as the visual elements or the extension of designing ideas and apply them into the design teaching system. They should deeply explore the essence of traditional culture art, reinforce the learning of regional culture theory, explore innovative teaching content and methods, bring the related information and achievements of teaching reform into the modern design teaching, and enrich and change teaching patterns. Teachers should make full use of the learning resources in the information environment, then construct a teaching mode which integrates modern design teaching with regional culture research and promote the inheritance and development of the regional culture in the modern art design teaching.

Combined with the teaching case and analysis of design practice, this paper emphasizes how to combine regional culture with design in the practical application project. Depending upon the different areas and different cultural characteristics, teachers should make specific analysis and find a suitable starting point and integration point in order to achieve the balance between times and region, tradition and modernization. Teachers should utilize techniques of theme expression flexibly, endow traditional symbols with new form and structure of modern significance, explore the accumulation and the connotation of regional culture after arrangement and combination so as to enrich curriculum resources in art design teaching and better apply it to modern design practice, which inherits the traditional culture at the same time. "Chinese localized design teaching system is based on China's traditional cultural ideas and aesthetic style and makes the integration of graphic language, pattern style and creative mode of thinking in native culture." Blending regional culture into the design teaching enables students to study the design theory and at the same time improve their traditional knowledge, performance ability, creative attitude, emotional expression and expression forms, etc. Chinese traditional folk art includes creation and modeling method and style which are unique and are of local characteristics. Only by combining the rich regional culture resources and the art design education can students absorb more cultural knowledge, participate in 
cultural transmission and creation so as to better fulfill the mission of inheriting and promoting traditional culture.

\section{REFERENCES}

[1] Lianhui. Constructing Art Design Teaching of Regional Culture Characteristics [J]. Journal of Gansu Advanced Normal University. 2011(5)

[2] Zuo Hanzhong. Chinese Folk Arts Model[M]. Hunan: Hunan Art Press. 2006.

[3] Xu Fengcai. A Global View of Central China Culture[M]. Beijing: Xinhua Press.2007.

[4] Xu Guangchun. Zhongyuan Culture and Prosperity---Xu Guangchun's Keynote Speech at Hongkong Symposium [M]. Henan People Press. 2007.

[5] Zheng Dongjun. Zhongyuan Culture and Research on Architecture in Henan[D]. Doctoral Dissertation in Tianjin University.2008.

[6] Zuo Mantang. Henan Folk House [M]. China Architecture and Building Press. 2007. 